\title{
IMPLIKASI PENDIDIKAN ISLAM DALAM PENDIDIKAN ANAK MENURUT IRWAN PRAYITNO
}

\author{
Zuyyina Candra Kirana \\ Dosen tetap STAI Hasanuddin Pare Kediri \\ Zuyyinasaadah99@gmail.com
}

\begin{abstract}
Education for children is a principle of human happiness must begin from childhood and is the best time to learn the correct method of life. Ability to capture and follow (lessons), and the sensitivity of receiving knowledge is still very strong in children. According to. Irwan Prayitno child is a very special figure, which in its development requires guidance and guidance from parents in order to realize the figure of a virtuous child. Educating children requires detailed description and precise data collection of the child's behavior. Data collection is needed to direct the potential in children. According to Irwan Prayitno in realizing the figure of a virtuous child, the child requires proper upbringing. According to him the proper education is education based on Islamic values. Because Islam is a perfect religion. It covers all aspects of human life. Including the issue of children's education who get a place in it, Islam is very concerned about families and children who are the basic foundation. on Islamic values as a reference in formulating the applied education. Based on the analysis, there are many similarities between educational concepts. Irwan Prayitno with the concept of Islamic education. So indirectly education. Irwan Prayitno has a close relationship with Islamic education.
\end{abstract}

Keywords: Islamic education and children's education

\section{Abstrak}

Pendidikan bagi anak merupakan prinsip kebahagiaan umat manusia harus dimulai sejak periode kanak-kanak dan merupakan masa terbaik untuk mempelajari metode hidup yang benar. Kemampuan menangkap dan mengikuti (pelajaran), serta kepekaan menerima ilmu masih sangat kuat pada diri anak. Menurut. Irwan Prayitno anak merupakan

Nazhruna: Jurnal Pendidikan Islam

Vol. 1 No 1 Maret 2018. Issn: 2614-8013. Hal. 61-79 
sosok sangat istimewa, yang dalam perkembangannya memerlukan arahan dan bimbingan dari orang tua agar terwujudnya sosok anak yang saleh. Mendidik anak memerlukan penggambaran secara rinci dan pendataan yang tepat terhadap perilaku anak. Pendataan tersebut diperlukan guna mengarahkan potensi dalam diri anak. Menurut Irwan Prayitno dalam mewujudkan sosok anak yang saleh tersebut, anak memerlukan didikan yang tepat. Menurutnya pendidikan yang tepat tersebut adalah pendidikan didasarkan pada nilainilai Islam. Sebab Islam merupakan agama yang sempurna. Didalamnya tercakup seluruh aspek kehidupan manusia. Termasuk juga masalah pendidikan anak yang mendapatkan tempat didalamnya, Islam sangat memperhatikan keluarga dan anak yang merupakan pijakan dasar. pada nilai-nilai Islami sebagai rujukan dalam memformulasikan pendidikan yang diterapkan. Berdasarkan analisis, didapat banyak kemiripan konsep antara pendidikan. Irwan Prayitno dengan konsep pendidikan Islam. Sehingga secara tidak langsung pendidikan. Irwan Prayitno mempunyai kaitan erat dengan pendidikan Islam.

\section{Kata kunci: pendidikan islam dan pendidikan anak}

\section{Pendahuluan}

Irwan Prayitno memandang pendidikan anak sebagai pendidikan dini yang segala perkembangannya memerlukan orang dewasa (orang tua) guna membangun potensi menuju pribadi yang cerdas dan soleh. Memberikan gambaran pendidikan anak, permasalahan seputar anak, penyelesaian dan cara pengembangan potensi anak kepada para orang tua dan guru sebagai orang-orang terdekat dalam dunia anak dan pendidik bagi mereka.

Dalam masa pertumbuhan anak, peran orang tua sangat penting disamping mereka harus menyediakan pengalaman yang tepat, menyediakan diri untuk bermain dengan anak juga bercakap-cakap dan bernyanyi bersamanya.Oleh karena itu orang tua dituntut mengetahui memahami hal-hal yang terkait dengan pendidikan dan perkembangan anak.Pendidikan dini bagi anak dan pengembangan yang merupakan prinsip kebahagiaan umat manusia harus dimulai sejak periode kanakkanak.Masa kanak-kanak merupakan masa terbaik untuk mempelajari 
metode hidup yang benar. Kemampuan menangkap dan mengikuti (pelajaran), serta kepekaan menerima ilmu masih sangat kuat

Pada diri anak bisa dikatakan manusia yang paling bahagia adalah mereka yang tumbuh besar dibawah pendidikan yang benar dan sifat-sifat mulia sejak kecil. Sehingga sewaktu besar sifat-sifat itu akan nampak pada dirinya tanpa paksaan ${ }^{1}$.

Dalam mendidik dan mengembangkan anak orang tua harus benar-benar memahami perilaku anak, harus mengerti apa motivasi anak. Untuk mencoba aktivitas fisik yang baru, bagaimana anak berfikir dan memproses informasi baru yang dibawa kepadanya.Anak adalah pribadi yang menakjubkan yang kadang ingin mencapai banyak hal sekaligus.Perkembangan psikologi, sosial dan kognitif anak bergantung pada kemampuan penguasaan ketrampilan motorik dan bahasanya dan begitu pula sebaliknya ${ }^{2}$. Oleh karena perlu bagi orang tua mengetahui tahap-tahap perkembangan anak dan hal-hal yang baru diperhatikan dan diajarkan kepada mereka.

\section{Pendidikan Anak Menurut Irwan Prayitno}

Proses belajar mengajar merupakan suatu kegiatan yang disengaja diciptakan dengan tujuan untuk merubah perilaku anak Anak dalam perkembangannya memerlukan bimbingan dan arahan agar segala potensi yang dimilikinya dapat diarahkan kepada hal-hal yang tidak bertentangan dengan fitrah-Nya, dimana fitrah disini merupakan tatanan yang ada pada diri manusia.Untuk itu mereka memerlukan pendidikan sebagai upaya pembinaan dan pengembangan kemampuan fitrahnya. Pendidikan (education) menurut Federick J. Mc Donald adalah Education is a process or an activity which is directed at producing desirable charges in the behavior of human beings, dari pendapat di atas nampak bahwa pendidikan merupakan proses dalam merubah tingkah laku.

Anak merupakan pribadi yang mempesona, dalam dirinya tersimpan aneka keluguan dan potensi. Dalam pendidikan, anak merupakan obyek, sehingga anak bisa dikatakan sebagai pusat pendidikan (menurut aliran Child Centered). Anak didik adalah anak yang sedang

${ }^{1}$ Falsafati Muhammad Taqi, Anak antara Kekuatan Gen dan Pendidikan (Bogor: Penerbit Cahaya, 2002), 206. $17-18$.

2 Prayitno Irwan, ed., Membangun Potensi Anak (Jakarta: Tarbiyatuna, 2002), 
tumbuh dan kembang baik ditinjau dari segi fisik maupun segi perkembangan mental. Perubahan yang terjadi padanya memerlukan pemahaman dan pengarahan yang menolongnya dalam seluruh kepribadian dan kemampuannya ${ }^{3}$

Menurut Irwan Prayitno anak merupakan sosok sangat istimewa, yang dalam perkembangannya memerlukan arahan dan bimbingan dari orang tua agar terwujudnya sosok anak yang saleh.Mendidik anak memerlukan penggambaran secara rinci dan pendataan yang tepat terhadap perilaku anak.Pendataan tersebut diperlukan guna mengarahkan potensi dalam diri anak.Menurut Irwan Prayitno dalam mewujudkan sosok anak yang saleh tersebut, anak memerlukan didikan yang tepat.Menurutnya pendidikan yang tepat tersebut adalah pendidikan didasarkan pada nilainilai Islam.Sebab Islam merupakan agama yang sempurna.Didalamnya tercakup seluruh aspek kehidupan manusia.Termasuk juga masalah pendidikan anak yang mendapatkan tempat didalamnya, Islam sangat memperhatikan keluarga dan anak. Allah SWT. menyebutkannya sebagai perhiasan dunia dan dijadikannya indah memandang anak dan keluarga ${ }^{4}$. Namun sebaliknya, anak bisa menjadi ujian dan cobaan apabila tidak dididik secara baik. Dengan demikian adalah suatu kewajiban para orang tua untuk mendidik secara baik dan benar, dilihat dari sudut-sudut ilmu pendidikan maupun dari syari'at Islam.

Allah SWT. menjadikan anak sebagai amanah yang telah dibekali potensi untuk disyukuri dan dipergunakan dengan baik. Target penciptaan manusia adalah ibadah dan menjadi khalifah oleh karena itu peran orang tua dalam membangun potensi anak sangat diutamakan; seperti pendidikan anak, dimulai dengan menyusui anak dan menjaga anak agar tetap dalam fitrah. Orang tua wajib bersikap baik dan kasih sayang terhadap anak, serta mendidiknya secara bertahap hingga mencapai kecerdasannya ${ }^{5}$.

Anak dalam perkembangannya mempunyai tugas yang sama dengan usianya. Namun realita dan praktek perkembangan anak berbedabeda antara anak satu dengan yang lain. hal ini disebabkan perbedaan

${ }^{3}$ Soemanto Wasty, Psikologi Pendidikan, Landasan Kerja Pemimpin Pendidikan, (Jakarta Pusat: Rineka Cipta, 1990), 165.

${ }^{4}$ Prayitno Irwan, ed., 24 Jam Bersama Anak (Jakarta: Tarbiyatuna, 2002), 5.

${ }^{5}$ Prayitno Irwan, 111. 
intelegensi, kepribadian, keadaan jasmani, keadaan sosial, bakat dan minat anak itu sendiri ${ }^{6}$.

Berdasarkan realita di atas Irwan Prayitno membagi perkembangan anak menjadi empat tahap perkembangan yaitu:

\section{Perkembangan usia balita}

Usia balita adalah usia marah karena aktifitas fisik seorang anak sering tidak sesuai dengan keinginannya. Karakter sering tidak mencukupi baginya untuk membuat dirinya dimengerti untuk menyampaikan keinginannya.

Sejak bayi, anak sudah memiliki kebutuhan berbahasa. Masa ini sangat penting terutama bagi tauhid anak. Dalam tahapan ini orang tua perlu mengajarkan berbahasa anak dengan baik. Anak akan cepat berkembang jika para orang tua sering berkomunikasi dengan anak. Bicara sebagai alat utama mengembangkan anak baik sosial dan emosi. Berbicara yang terganggu akan mengganggu perkembangan emosi dan sosialnya. Oleh karena itu orang tua penting mengetahui kunci penting melatih bicara anak agar segala potensi baik kognitif, sosial dan emosi dapat teraktualkan, ${ }^{7}$ dan segala permasalahannya dapat diatasi.Anak balita memiliki sifat sangat menuntut segala keinginan yang muncul mengharuskan agar terpenuhi keinginannya.Rengekan dan tangisan menjadi kekuatan anak untuk mengatur orang tua. Tetapi pada tahap perkembangan tersebut anak sedang mengembangkan kepercayaan, rasa aman dan percaya diri yang akan mempengaruhi dunianya secara positif.

\section{Perkembangan usia sekolah}

Pada tahap perkembangan ini, anak menjadi lebih mengerti dan mampu membedakan perbuatan baik atau buruk. Sekolah merupakan tempat sosialisasi bagi anak. Pada usia 6-9 tahun anak dirangsang untuk belajar mengembangkan indera. Erikson mengkategorikan tujuan utama tahap perkembangan ini sebagai "rajin vs rendah diri”. Pada masa ini anak larut dalam usaha penyempurnaan kemampuannya. Pada masa ini mereka akan berlatih menguasai keterampilan, kepribadian dan konsep diri dengan ditentukan oleh apa yang bisa mereka lakukan dengan baik. Anak usia 10-

${ }^{6}$ Wahid Abdul, Menumbubkembangkan Minat dan Bakat Anak (Yogyakarta: Pustaka Pelajar, 1998), 108.

${ }^{7}$ Irwan Prayitno and Erwin FS, Ajaklah anak bicara (Bekasi: Pustaka Tarbiatuna, 2003), 3. 
11 tahun, mereka akan merasa percaya diri dan bangga terhadap kemampuannya.

\section{Perkembangan usia pra remaja}

Anak usia remaja ( \pm 12 tahun) mereka menganggap kelompok sebagai suatu yang penting. Pada usia ini membantah menjadi sesuatu yang wajar, membandingkan tingkah laku serta kepercayaan teman sebaya begitu sangat berarti.

\section{Perkembangan usia remaja}

Usia 12-19 tahun disebut usia remaja, pada fase ini ditandai dengan pubertas dan perkembangan intelektual serta kemampuan untuk mengatasi masalah-masalah yang kompleks dan belajar memenuhi permintaan sosial.

Seorang pendidik mempunyai tanggung jawab membawa muridmuridnya pada satu taraf kematangan tertentu. Pendidik adalah individu yang mampu melaksanakan tindakan mendidik dalam satu situasi pendidikan untuk mencapai tujuan pendidikan ${ }^{8}$.

Seorang pendidik adalah orang dewasa yang bertanggung jawab, sehat jasmani dan rohani, mampu berdiri sendiri dan mampu menanggung resiko dari segala perbuatannya. Dalam memberikan pelayanan pendidikan mereka juga dituntut kerelaan dan kesediaan agar proses pendidikan berjalan baik ${ }^{9}$. Sehingga tugas seorang pendidik adalah membimbing anak dalam proses pertumbuhannya agar mereka dapat berdiri sendiri.

Menurut Irwan Prayitno, pendidik terpenting bagi anak adalah orang tua. orang tua adalah orang dewasa dimana mereka harus menyesuaikan diri mereka dengan pribadi anak. Menerima watak anak dan memahami bentuk-bentuk perilaku anak dan menghasilkan kesesuaian, empati antara orang tua dan anak. Anak merupakan amanah bagi orang tua. Allah menjadikan manusia dengan target manusia beribadah pada-Nya dan menjadi khalifah di muka bumi. Oleh karena itu peran seorang pendidik adalah sosok arsitektur pembentuk jiwa dan watak anak didik

${ }^{8}$ Yusuf Muri, Pengantar Ilmu Pendidikan (Jakarta: Kencana Prenada Media Group, 1982), 54.

${ }^{9}$ Purwanto Ngalim, Ilmu Pendidikan Teoritis dan Praktis, 17th ed. (Bandung: Remaja Rosdakarya, 2006), 3. 
yang berguna bagi agama, nusa dan bangsa ${ }^{10}$ serta membangun segala potensi anak didik dalam rangka pencapaian tujuan pendidikan.

Kehadiran orang tua dalam perkembangan anak sangat diperlukan, bahkan selam 24 jam orang tua harus memantau dan pada saat dibutuhkan orang tua berada disisi anak. Menurut Irwan Prayitono orang tua harus bahu membantu dalam mendidik anak secara islami. Ketika seorang ibu mengandung mereka harus menjaga janin tersebut dengan sebaik-baik perawatan dan mulai mengarahkan pendidikan tauhid padanya. Setelah anak lahir pendidikan dan yang harus mereka penuhi kepada anak seperti:

1. Memberikan nama yang baik

Nama akan membentuk konsep diri yang berpengaruh pada potensi anak. Nama yang baik akan menggambarkan diri yang baik pula. Nama pada dasarnya menjadi penilaian kepada seorang anak.

2. Menyusui

Menyusui merupakan ajaran Islam, dengannya anak akan terpenuhi kebutuhan fisik dan emosi berupa kasih sayang, kelembutan, kehangatan dan pertahanan. Menyusui dianjurkan hingga 2 tahun.

3. Membesarkan anak

Membesarkan anak berarti mendidik anak sesuai dengan syari'at Islam, dengan cara menyekolahkan dan mendidiknya dengan baik.

4. Menjaga anak

Beberapa kegiatan orang tua dalam menjaga anak adalah menyusui, memuliakan anak, meningkatkan budi pekertinya, memelihara anak dan mendewasakan anak.

5. Menyayangi anak

Dalam Islam mengajarkan kasih sayang kepada siapapun. Orang tua diharuskan menyayangi anak-anak.

6. Bermain bersama anak

Dunia anak adalah bermain, khususnya bagi anak berusia di bawah lima tahun. Belajar pada anak balita biasanya dengan cara bermain. Bermain pada anak akan mengembangkan kemampuan motorik sehingga anak cepat bergerak dan melakukan kegiatan fisik lainnya.

${ }^{10}$ Syaiful Bahri Djamarah, Guru dan anak didik dalam interaksi edukatif Jakarta: Rineka Cipta, 2005), 36. 
7. Mendidik anak

Orang tua bertanggung jawab terhadap pendidikan formal maupun non formal anak-anak. Diantara tanggung jawab pendidikan tersebut adalah mengajak shalat, berbuat baik, menghindarkan diri dari perbuatan mungkar dan mewasiatkan kesabaran.Dalam hal ini setiap orang tua berkewajiban mendidik anaknya agar mampu beribadah kepada Allah melalui pendidikan.

8. Memuliakan anak

Anak adalah manusia kecil yang mempunyai hak sama dengan manusia dewasa. Islam menyuruh memuliakan anak dan mengajarkan akhlak yang baik kepada mereka.

9. Adil kepada anak

10. Mengajarkan ilmu

11. Mendidik jasmani anak

12. Mengajarkan akhlak

13. Mengajak anak beramal

14. Mengikuti sunnah Nabi

Berkaitan dengan hal di atas peranan orang tua begitu penting. Pengalaman belajar yang diterima anak dalam keluarga mulai dari kandungan, masa kanak-kanak dan pra sekolah akan sangat menentukan masa depan anak yang bersangkutan. Pemahaman terhadapnya akan membantu para orang tua untuk mengarahkan anak secara baik ${ }^{11}$. AH.Markum (ahli anak terkemuka) mengatakan "siapapun dapat mengasuh anak secara berhasil asalkan mengetahui betul tahap dan tugas perkembangan, sehingga dalam masing-masing tugas perkembangan dapat diajak maju dan dipacu mencapai perkembangan optimal ${ }^{12}$ mengaktualkan potensi anak (kognitif, sosial dan emosi). Tetapi perlu diingat dalam melatih bicara perlu mengetahui kunci pentingnya, melatih bicara anak diantaranya dengan membiasakan orang tua bicara apapun ketika bersama anak dan melatih anak berbicara sesuai dengan usia perkembangan.

${ }^{11}$ Endang Poerwanti and Nur Widodo, Perkembangan Peserta Didik (Malang: Universitas Muhammadiyah Malang, 2002), 4.

${ }^{12}$ J Federick, Educational Psychology (Wadsworth: Publishing Company, 1965), 4. 


\section{Materi Pendidikan Anak}

Pengetahuan atau mata pelajaran dalam kurikulum menempati tempat yang penting untuk memberi jawaban terhadap apa yang dikerjakan untuk menciptakan manusia yang dicita-citakan ${ }^{13}$. Dalam pendidikan pemberian materi harus bertahap dan disesuaikan dengan usia dan perkembangan anak didik (obyek pendidikan).

Menurut Irwan Prayitno perkembangan anak sama dengan usianya. Namun dalam praktek dan kenyataan, perkembangan antara satu dengan yang lain adalah berbeda. Setiap usia yang dicapai oleh anak, memiliki hal-hal yang penting dalam perkembangannya. Menurut Irwan Prayitno terdapat enam kegiatan pembelajaran bagi anak berdasarkan tingkatan umur, yaitu:

\section{Kegiatan anak hingga usia dua tahun}

Pada usia awal anak banyak melakukan berbagai gerakan baik kaki, tangan dan kepala. Pada usia dua bulan anak menggerakkan tangandan kaki secara aktif. Anak menoleh kepala ke samping kanan dan kiri mencarimencari sumber bunyi. Pada usia empat bulan anak bisa memegang mainan oleh karena itu berilah mainan yang dapat merangsang dan bisa dipegang ke tangan. Hingga usia enam bulan anak mulai meraih dan menggapai.

Pada usia 0-6 bulan merupakan fase I. Berbagai penelitian menunjukkan bayi pada usia awal, ini adalah seorang pelajar yang aktif (an active learner). Pada usia 0-6 bulan sebaiknya anda sensitif terhadap tingkah laku anak, tingkah laku tertentu menunjukkan sesuatu yang mereka inginkan sebagai contoh menangis mungkin anak lapar, ngantuk, basah karena kencing atau sakit. Oleh karena itu perhatian terhadap perkembangan dan perilaku anak sangat diperlukan.

Pada usia 6-9 bulan anak sudah mampu berdiri tanpa berpegangan. Pada usia ini anak bisa memanggil ibu/ayah. Pada usia ini orang tua harus mulai mencontohkan secara benar, mana yang boleh dan mana yang tidak. Selain itu anak harus diajarkan mandiri yang sesuai dengan perkembangannya.

${ }^{13}$ Hasan Langgulung, Manusia Dan Pendidikan, cet ke 1 (Jakarta: Pustaka AlHusna, 1986), 152. 
Pada usia 6-12 bulan sering disebut sebagai usia infant. Pada usia ini anak postur tubuh anak menjadi kokoh dan arah perilaku mulai berubah. Dari pusat pada diri sendiri menuju ke ekspresi atau menjelajah dunia disekitarnya. Dengan cara seperti itu, anak memperoleh pengalaman dan kemampuan untuk membedakan orang lain.

Pada usia 1-2 tahun atau sering disebut the early toddler. Pada usia ini anak suka berjalan, mendaki atau menaiki sesuatu, jatuh, menabrak sering kali terjadi. Peran orang tua pada saat ini adalah mendukung serta mengarahkan gerak anak. ada usia ini orang tua jangan mengucapkan katakata yang tidak baik dihadapan anak. Walaupun anak belum bisa menyebutkan tetapi suatu saat anak akan menirukan karena pada dasarnya anak belajar segala sesuatu dari pengalamannya.

\section{Kegiatan anak dua tahun-empat tahun}

Usia anak antara 2-4 tahun, maupun balita tahap 2 (2-3 tahun) dan usia pra sekolah bagi anak (3-4 tahun). Pada usia ini rasa keingintahuannya dan keinginan untuk mengeksplorasi semakin besar. Perkembangan yang menggembirakan adalah bicara anak semakin lancar dari proses sosialisasi semakin baik. Pada usia ini orang tua bisa mengajarkan berbagai kegiatan pembelajaran seperti di bawah ini:

Pengenalan warna-warna dasar dengan memisahkan benda-benda berwarna melalui permainan-permainan yang menyenangkan dan cara mudah.

Pengenalan permainan-permainan kreatif bagi anak seperti membuat permainan dari potongan gambar di majalah/koran, belajar menyusun balok-balok dan membuat rumah-rumahan dari kardus.

a. Mengajarkan permainan musik dan lagu mengingat anak mulai bicara pesat sehingga dengan pelajaran tersebut akan lebih meningkatkan kemampuan bicara dan pengembangan pola ritme musik dalam kepala anak.

b. Membacakan cerita anak dan mendorong anak untuk membaca sendiri.

c. Ajarkan anak untuk melakukan kegiatan yang mengasah kemahiran seperti latihan fisik anak dengan menendang bola, melompat, berdiri dengan satu kaki, lompat tali dan sebagainya.

d. Ajarkanlah anak untuk mengenal nilai-nilai keagamaan. 


\section{Kegiatan anak usia empat tahun-enam tahun}

Pertumbuhan dan perkembangan anak usia ini berbeda dengan usia 2 tahun. Gerakkan anak menjadi lebih mudah dan ia senang beraktivitas fisik. Kemampuan konsentrasinya meningkat dan sering kali mengajukan pertanyaan-pertanyaan yang tidak disangka-sangka. Cara berpikir pada anak usia ini dituangkannya dalam ucapan, gambar-gambar dan segala sesuatu yang dikerjakannya. Oleh karena itu anak perlu diajarkan seperti berikut:

a. Latihan kemampuan otak anak, contoh dengan permainan botol dan tutup botol

b. Ajarilah anak menyanyi dengan lagu-lagu yang mengandung peran moral.

c. Ajarilah hafalan al-Qur'an dan hadits serta do'a-do'a sebelum dan sesudah anak melakukan kegiatan.

d. Mengajarkan belajar matematika yang menyenangkan sehingga membantu anak memahami ukuran contoh permainan memilih kancing yang akan mengajarkan tentang bersamaan dan perbedaan bentuk.

e. Kenalkanlah anak tentang ilmu pengetahuan dari lingkungan kepada anak, seperti mengapa batu yang dilempar ke kolam tenggelam.

f. Lakukan permainan keseimbangan yang meningkatkan koordinasi gerak keseimbangan dan kontrol tubuh anak seperti bermain tali.

g. Ajarilah anak mengenal tentang nilai-nilai agama seperti melakukan puasa dan mengajarkan hikmah, di dalam ibadah-ibadah yang dilakukan sehingga anak mendapatkan pendidikan ruhani.

\section{Kegiatan anak usia enam tahun-delapan tahun}

Pada usia ini, ada beberapa hal yang perlu diajarkan kepada anakyaitu:

a. Ajarkanlah anak untuk menghafal ayat-ayat bacaan shalat dan anak harus mempraktekkan shalat yang sebenarnya.

b. Ajarilah anak manfaat zakat fitrah serta hikmah didalamnya.

c. Latihlah anak kegiatan yang melatih (mengasah) kemahiran, contoh anak diajarkan melakukan kejar-kejaran bola, kegiatan ini bertujuan menjaga keseimbangan. 
d. Latihlah otak anak dengan mengembangkannya lewat permainan, kegiatan yang bisa dilakukan contohnya menghubungkan titik-titik menjadi garis.

\section{Kegiatan anak usia delapan tahun-sepuluh tahun}

a. Latih kemampuan otak anak dengan kegiatan yang menguji keahlian anak dalam menghubungkan satu kata dengan kata lainnya.

a. Latihlah kemahiran anak. Pada usia ini ajak anak untuk menguasai dasar-dasar bermain lompat tali.

b. Ajarilah anak untuk mengamalkan kewajiban sebagai seorang muslim.

c. Tingkatkan kemampuan mengeja dan perbendaharaan kata-kata anak dengan kegiatan membentuk kata baru dengan huruf yang ada dan sama.

\section{kegiatan anak sepuluh tahun-dua belas tahun ke atas}

b. Sebagian anak usia ini sudah baligh oleh karena itu orang tua harus tegas kepada anak-anaknya dalam menjalankan nilai-nilai Islam. Ajarkan anak melakukan dengan tertib kewajibannya sebagai seorang muslim.

c. Ajarkanlah anak anda dengan permainan fisik di luar ruangan seperti camping dan hiking.

d. Ajarilah anak untuk mempelajari ilmu pengetahuan dari lingkungan.

Orang tua merupakan pendidik pertama dan utama. Mereka harus mendidik anak berdasarkan pendidikan agama, budi pekerti, sopan santun, estetika, kasih sayang, rasa aman dasar-dasar mematuhi peraturan.

Pendidikan budi pekerti adalah jiwa dari pendidikan Islam, dan Islam telah menyimpulkan bahwa pendidikan budi pekerti dan akhlak adalah jiwa pendidikan Islam, pencapaian akhlak secara sempurna adalah tujuan sebenarnya. Para ahli pendidikan Islam sepakat bahwa maksud dari pendidikan dan pengajaran bukanlah memenuhi otak anak didik dengan segala macam ilmu yang belum mereka ketahui tetapi ialah mendidik akhlak dan jiwa mereka, menanamkan fadhilah (keutamaan), membiasakan mereka dengan kesopanan yang tinggi, mempersiapkan mereka untuk suatu kehidupan yang suci seluruhnya ikhlas dan jujur.

Bertolak dari al-Qur'an di atas bahwa Islam adalah agama yang sesuai dengan watak alamiah manusia. Dengan suatu tujuan adalah penghambaan seorang kepada rabb semesta alam, tumbuh imannya, taat beribadah dan 
berakhlak terpuji.Dengan demikian tujuan pendidikan Islam adalah mempersiapkan manusia yang abid yang menghambakan dirinya kepada Allah SWT.

\section{Pendidikan Anak Menurut Irwan Prayitno Ditinjau dari Pendidikan Islam}

Untuk memahami pendidikan anak Irwan Prayitno mengenai bagaimana cara ideal dalam mendidik anak, tidak lepas dari komponenkomponen pendidikan yang terlibat didalamnya. Diantara komponenkomponen itu adalah peserta didik, pendidik, interaksi pendidikan, tujuan dan materi pendidikan. Interaksi antara komponen-komponen pendidikan tersebut akan menentukan kualitas dan tercapainya suatu maksud dari proses pendidikan.

Pandangan Irwan Prayitno tersebut jika dikaitkan dengan pendidikan Islam akan terlihat kemiripan dalam memposisikan sosok anak.

Dalam Islam anak merupakan makhluk Allah yang diciptakan untuk mengabdi kepada-Nya (untuk beribadat kepada-Nya). Firman Allah:

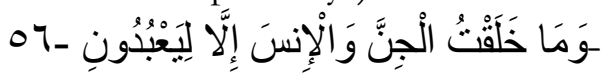

Artinya: Tidak. Aku ciptakan jin dan manusia melainkan supaya mereka menyembah-Ku. (QS. Adz-Dzariyaat: 56).

Selain untuk beribadat kepada Allah manusia diciptakan untuk menerima dan melaksanakan ajaran-ajaran-Nya, sehingga mereka ditempatkan pada kedudukan mulia sebagaimana dalam firman Allah:

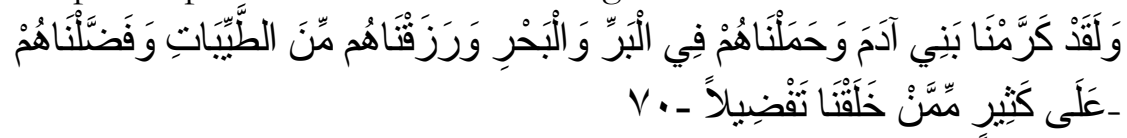

Artinya: Dan sesunggubnya telah Kami muliakan anak-anak Adam (manusia), Kami tempatkan mereka itu di darat dan di laut. Kami beri mereka rezeki yang baik-baik dan Kami lebibkan mereka dari makbluk. Kami yang lain. (QS. alIsra: 70)

Berdasarkan kedua ayat tersebut di atas Islam memuliakan anak dengan membekali akal dan ilmu. Akal untuk berfikir dan ilmu sebagai alat untuk menguasai alam ini dan meningkatkan iman dan taqwanya. Keduanya mempunyai peran penting dan berkaitan antara satu dengan yang lainnya.

Dari uraian di atas mengenai anak sebagai peserta didik, jelaslah bahwa konsep peserta didik dalam pendidikan anak Irwan Prayitno telah 
mencakup apa yang menjadi pandangan pendidikan Islam. Keduanya sama-sama memposisikan anak dalam tempat yang mulia. Keduanya memandang penting memberikan pendidikan yang tepat bagi anak, disebabkan adanya anak di dunia mengakibatkan konsekuensi bagi pada pendidik, sebuah konsekuensi yang akan dimintai pertanggungjawabannya kelak di yaumilakbir nanti.

Demikian juga konsep pendidikan Irwan Prayitno kita melihat adanya sisi positif dari pendidikan yang ditawarkan Irwan Prayitno begitu memperhatikan secara detail hal-hal yang terkait dengan pendidikan anak, dimulai dari janin hingga ia dewasa. Selain itu Irwan Prayitno dalam mengkonsep pendidikan bagi peserta didik didasarkan pada suatu sumber hujah yang kuat yaitu al-Qur'an dan Sunnah sebagai sumber inspirasi dalam mengkonsep pendidikan anak. Sehingga akan didapati berbagai rambu-rambu penting yang bisa diterapkan bagi para pendidik.

Dalam proses pendidikan antara pendidik dan anak didik ibarat dua sisi mata uang, antara keduanya tidak dapat dipisahkan dan saling terkait.Irwan Prayitno memandang pendidik sebagai sosok yang memegang peran penting terhadap arah pendidikan yang ingin dicapai dalam suatu proses belajar mengajar. Proses belajar mengajar sebagai inti dari pendidikan akan terlaksana dengan baik ketika pendidik sebagai pemeran utama, mampu menjalankan tanggung jawabnya.

Menurut Irwan Prayitno pendidik tersebut, keluarga merupakan basic awal pendidikan anak. Keluarga merupakan persekutuan hidup primer dan alami antara seorang pria dan wanita yang diikat oleh perkawinan dan cinta kasih. Seorang pria dan wanita ketika telah diikat oleh ikatan suci sebuah perkawinan menurut Irwan Prayitno secara otomatis dan koati akan mengemban amanah untuk mendidik dan mengarahkan anak-anak mereka pada suatu tujuan yang sesuai dengan fitrahnya.

Dalam konsep pendidikan anak Irwan Prayitno, setiap orang tua dalam melakukan pendidikan bagi anak-anak mereka adalah selama 24 jam. 24 jam disini dimaksudkan secara kuantitatif orang tua tidak harus bersama anak selama 24 jam full tetapi lebih kepada secara kualitatif orang tua melakukan pengawasan terhadap tumbuh kembang anak dan berada disisi anak ketika mereka membutuhkan. Selain itu mereka harus memberikan lingkungan edukatif baginya. 
Pendidikan anak dimulai ketika anak berupa janin hingga anak menjadi dewasa. Pendidikan awal pada anak menurut Irwan Prayitno memegang peranan penting terhadap perkembangan selanjutnya. Menurutnya dari kecil anak harus diajarkan nilai-nilai yang didasarkan pada nilai-nilai yang baik dalam hal ini nilai-nilai Islami. Mengapa harus nilai-nilai islami? Menurut Irwan Prayitno nilai-nilai Islami merupakan nilai-nilai yang secara lengkap memberikan tuntunan yang paripurna yang terkandung didalamnya ajaran aqidah, ibadah, akhlaq, kemasyarakatan, kejiwaan, jasmani, intelektualitas dan kesehatan.

Pendidikan anak berawal dari keluarga. Keluarga merupakan lingkungan pendidik awal bagi putra-putri mereka.Tetapi mengingat anak didik memerlukan ilmu-ilmu lain yang berhubungan dengan kebutuhan hidupnya maka para orang tua perlu mempercayakan pendidikan kepada sekolah (guru). Guru merupakan tokoh sentral yang dipercaya masyarakat untuk memberikan pendidikan bagi anak-anak mereka. Guru sebagai pendidik di sekolah diharapkan mampu membina, membimbing dan mengarahkan anak didik sesuai harapan para orang tua. Dari uraian di atas guru mempunyai tanggung jawab berat sebagai penerus pendidikan di lingkungan keluarga. Oleh karena itu seorang guru harus menjadi pendidik dan pembina yang baik bagi anak didiknya.

Seorang guru haruslah orang yang mampu mengarahkan anak didiknya menuju suatu kebahagiaan dunia dan akhirat.Sehingga guru sebagai seorang pendidik idealnya harus memenuhi syarat-syarat di antaranya bersifat rabbani, ikhlas, sabar, jujur, luas wawasan keilmuannya, tegas dan memahami psikologi anak, peka terhadap setiap permasalahan dan fenomena kehidupan.Menurut Irwan Prayitno seorang pendidik harus memahami masing-masing anak didik beserta kepribadian yang cukup beragam di antara mereka. Seorang pendidik harus menyadari bahwa mereka menghadapi tipe-tipe yang bervariasi dengan bakat, kemauan, potensi yang berbeda-beda. Walaupun mereka lahir kembar seorang pendidik pasti akan menemui titik perbedaan yang menuntut kreatifitas, penanganan dan arahan berbeda dari para pendidik. Apalagi di lingkungan sekolah guru dihadapkan dengan keberagaman karakteristik baik fisik, gaya dan cara bertindak, berbicara, berkomunikasi dan kemampuan-kemampuan lain. sehingga bagi para guru penting memahami kecakapan dan kepribadian anak didiknya. Hal tersebut terjadi dikarenakan 
pola pendidikan keluarga yang beragama dari masing-masing individu. Sehingga seorang pendidik diharapkan mengarahkan anak didik dan menanamkan nilai-nilai yang baik, dalam hal ini adalah nilai-nilai yang sesuai dengan ajaran Islam.

Pendidik menurut Irwan Prayitno ada 3 orang tua (keluarga), guru dan lingkungan. Hal tersebut senada dengan pendidikan menurut pendidikan Islam. Mengenai peran dan fungsi pendidik antara Irwan Prayitno dan pendidikan Islam adalah sama yaitu memberikan pendidikan yang tepat bagi anak dan mengarahkan anak (peserta didik) pada kedewasaan serta menjadikan mereka makhluk yang taat kepada sang penciptanya.

Fungsi dan peran serta pendidik antara Irwan Prayitno dan pendidikan Islam adalah sama. Tetapi Irwan Prayitno dalam memaparkan peran antara ketiga pendidik kurang proporsional. Irwan Prayitno terlalu memfokuskan pada peranan penting orang tua dan kurang mengekspos peran dua pilar lain (guru dan lingkungan). Peran orang tua memang vital karena mereka adalah pendidik awal bagi anak (peserta didik). Tetapi di sisi lain ada segi positif pada pendidikan anak Irwan Prayitno mengenai pendidik. Digambarkan di sana bahwa peran pendidik adalah urgen sehingga terdapat penekanan pada peran pendidik yaitu orang tua sebagai basic education bagi anak. Menurutnya keberhasilan pendidikan akan bergantung dari peran orang tua dalam mendidiknya.

Irwan Prayitno sebagai seorang pendidik memandang proses pendidikan sebagai upaya pembinaan akhlak menuju terbentuknya kepribadian muslim yang memberikan manfaat kepada diri dan lingkungan sosial dan mampu menyelamatkan diri anak dari perbuatan-perbuatan yang tidak baik menuju kepribadian muslim yang utuh, merupakan inti dari proses pendidikan yang dilakukan. Pendapat Irwan Prayitno pendidikan Islam yang tidak terlepas dari sebuah tujuan yaitu kepribadian seorang yang membuatnya menjadi insan kamil dengan pola takwa. Sebuah pendidikan yang menjadikan pendidikan budi pekerti sebagai jiwa dari pendidikan tersebut dan pencapaian akhlak secara sempurna sebagai tujuan yang sebenarnya, mempunyai kesamaan dan arah/sasaran yang dicapai hampir sama. Keduanya menekankan pada perbaikan dan pembinaan akhlak sebagai sasaran penting dari proses pendidikan yang dilakukan. Tujuan pendidikan Irwan Prayitno tersebut jika dibandingkan oleh tokoh 
pendidikan Islam seperti Prof. Hasan Langgulung yang merumuskan tujuan pendidikan Islam dalam suatu ishlah untuk mencari fadhilah, bahwa kurikulum pendidikan Islam berintikan akhlak yang mulia dan mendidik jiwa adalah sama.

Dalam pendidikan Irwan Prayitno, materi dikemas dengan sifatsifat dan karakteristik yang mengacu pada pemikiran Islami dan diarahkan kepada tujuan pendidikan yang dilandasi kaidah-kaidah keislaman. Mengenai pendidikan anak Irwan Prayitno memperhatikan hal-hal seperti perhatian terhadap fitrah manusia dan mengarah pada pencapaian keikhlasan, ketaatan dan penghambaan kepada Allah. Dalam materi pendidikan yang dikemasnya juga mendasarkan pada perkembangan para peserta didik sebagai objek pendidikan.

\section{Kesimpulan}

1. Pendidikan Islam merupakan pendidikan yang didasarkan pada nilainilai dasar yang terkandung dalam al-Qur'an dan as-Sunnah. Pendidikan Islam merupakan proses usaha mengubah tingkah laku individu dalam kehidupan pribadi atau kehidupan kemasyarakatan. Pendidikan sebagai aspek yang berperan pokok dalam membentuk generasi masa datang diarahkan untuk menghasilkan manusia yang berkualitas dan bertanggungjawab. Proses pendidikan dalam Islam merupakan sarana dalam pengembangan segenap potensi manusia menuju terciptanya pribadi muslim. Melihat urgensi pendidikan bagi anak di atas, proses pendidikan dilaksanakan ketika anak masih berupa janin hingga dewasa. Hal tersebut dilakukan mengingat masa anak merupakan masa-masa yang potensial dalam pengembangan potensi dan pembinaan menuju sasaran yang diinginkan.

2. Irwan Prayitno merupakan tokoh pendidik dan psikolog. Dalam konsep pendidikan yang diuraikan, pada dasarnya bersumber pada anak sebagai amanah Allah bagi orang tuanya. Keberadaan mereka memunculkan tanggung jawab pendidikan bagi orang tua untuk mendidik dan mengarahkan mereka menuju suatu tujuan tertentu yaitu membentuk sosok muslim yang utuh, berakhlak baik dan teroptimalisasi serta teraktualkan segala potensi yang ada padanya sehingga terwujud pribadi saleh, cerdas, kreatif, produktif dan komitmen terhadap nilai-nilai ilahi, dalam rangka menjalankan tugasnya sebagai khalifah fil al-Ardl. Oleh karena itu peran pendidik 
dalam mengarahkan anak menjadi sangat penting, Berawal dari konsep itu Irwan Prayitno memandang perlunya sebuah pendidikan yang tepat bagi anak yang dapat menyentuh setiap potensi baik kognitif, fisik, sosial, mental dan psikomotor dan mendasarkannya pada nilainilai yang sesuai dengan fitrah anak yaitu pendidikan yang berdasarkan nilai-nilai Islami dengan sumber al-Qur'an dan Sunnah sebagai pedoman pelaksanaannya.

3. Dewasa ini peran pendidikan semakin penting, di era globalisasi perkembangan zaman ketepatan dalam memilih dan menerapkan pendidikan merupakan penentu terhadap pembentukan generasi mendatang. Menghadapi pengaruh dan tantangan zaman tersebut Irwan Prayitno merasa perlu menyusun dan menformulsikan pendidikan yang cocok diterapkan yang mengarah pada pribadi yang cerdas, kreatif, produktif dan tetap berpegang teguh pada nilai-nilai Illahi. Sehingga Irwan Prayitno merasa berkewajiban untuk memformulasikan pendidikan yang menyentuh dan mengembangkan potensi-potensi manusia tanpa mengesampingkan fitrah dari manusia itu sendiri. Menurutnya, pendidikan akan dapat mencapai sasaran ketika ilmu-ilmu yang ada diformulasikan dan didasarkan pada nilainilai yang hakiki yaitu nilai-nilai Islam yang mendasarkan pada alQur'an dan Sunnah sebagai sumber rujukan. selain itu Irwan Prayitno merasa penting untuk melakukan pengarahan kepada peserta didik. Hal tersebut didasarkan pada sebuah hadits Nabi Muhammad SAW sampaikan pemahaman kepada manusia sesuai dengan kemampuannya. Tahapan menurut Irwan Prayitno adalah sesuatu proses yang perlu diperhatikan bagi para pendidik, proses tersebut dimaksudkan agar tujuan yang diinginkan dapat tercapai. 


\section{Referensi}

Abdul, Wahid. Menumbubkembangkan Minat dan Bakat Anak. Yogyakarta: Pustaka Pelajar, 1998.

Endang Poerwanti, and Nur Widodo. Perkembangan Peserta Didik. Malang: Universitas Muhammadiyah Malang, 2002.

Federick, J. Educational Psychology. Wadsworth: Publishing Company, 1965.

Irwan Prayitno, and Erwin FS. Ajaklah anak bicara. Bekasi: Pustaka Tarbiatuna, 2003.

Langgulung, Hasan. Manusia Dan Pendidikan. Cet ke 1. Jakarta: Pustaka Al-Husna, 1986.

Muhammad Taqi, Falsafati. Anak antara Kekuatan Gen dan Pendidikan. Bogor: Penerbit Cahaya, 2002.

Muri, Yusuf. Pengantar Ilmu Pendidikan. Jakarta: Kencana Prenada Media Group, 1982.

Ngalim, Purwanto. Ilmu Pendidikan Teoritis dan Praktis. 17th ed. Bandung: Remaja Rosdakarya, 2006.

Prayitno Irwan, ed. 24 Jam Bersama Anak. Jakarta: Tarbiyatuna, 2002. , ed. Membangun Potensi Anak. Jakarta: Tarbiyatuna, 2002.

Syaiful Bahri Djamarah. Guru dan anak didik dalam interaksi edukatif. Jakarta: Rineka Cipta, 2005.

Wasty, Soemanto. Psikologi Pendidikan, Landasan Kerja Pemimpin Pendidikan,. Jakarta Pusat: Rineka Cipta, 1990. 